\title{
Antinociceptive Effect of the Ethanol Leaf Extract of Balanites aegyptiaca Linn in Albino Rats
}

\author{
10. A. Sodipo, ${ }^{* 2}$ J. Yakubu, ${ }^{1}$ A.M. Dungus and ${ }^{3}$ B. Wampana \\ ${ }^{1}$ Department of Clinical Pharmacology and Therapeutics, College of Medical Sciences, University of Maiduguri, PMB 1069, Maiduguri, Nigeria \\ 2Department of Chemistry, Faculty of Science, University of Maiduguri, PMB 1069, Maiduguri, Nigeria \\ 3Department of Pharmacology, Faculty of Veterinary Medicine, University of Maiduguri, PMB 1069, Maiduguri, Nigeria
} [Corresponding Author: E-mail: jamesyakubu96@gmail.com]

\section{ABSTRACT}

Balanites aegyptiaca is a medicinal plant that has been used in a variety of folk medicines in India and Africa for the treatment of different ailments such as syphilis, jaundice, liver and spleen problems, epilepsy, yellow fever. This research aimed at investigating the phytochemical constituents, acute toxicity, antiinflammatory and antinociceptive activities of the ethanol extract of Balanites aegyptiaca (EEBA) leaves. The plant material was extracted using ethanol as solvent. The dried ethanol extract was screened for the presence of phytochemicals; Acute toxicity (LD50) was determined using Lorke's method while antiinflammatory and antinociceptive activities were evaluated using hot plate and tail immersion methods in albino rats. Results of the study revealed that phytochemical constituents such as flavonoids, carbohydrates, saponins and glycosides were found in the EEBA, intraperitoneal LD 50 of $2154 \mathrm{mg} / \mathrm{kg}$ shows the substance is non-toxic. The EEBA produced significant $(p<0.05)$ and dose dependent anti-inflammatory and antinociceptive activities at all test doses (200, 400 and $600 \mathrm{mg} / \mathrm{kg}$ ). The presence of the phytochemicals detected might be responsible for the demonstrated anti-inflammatory and antinociceptive activities in the plant extract.

KEYWORDS: Phytochemical, Anti-inflammatory, Antinociceptive, Balanites aegyptiaca

\section{INTRODUCTION}

Pain is defined as an unpleasant feeling that is conveyed to the brain by sensory neurons. The discomfort signals actual or potential injury to the body. However, pain is more than a sensation or the physical awareness of pain; it also includes perception, the subjective interpretation of the discomfort. Perception gives information on the pain's location, (usually initiated by noxious stimulus and transmitted over a specialized neural network to the central nervous system) intensity, and something about its nature. The various conscious and unconscious responses to both sensation and perception, including the emotional response, which add further definition to the overall concept of pain. (Kumar and Elavarasi, 2016). Pain is an unpleasant sensation localized to a part of the body. It is often described in terms of a penetrating or tissuedestructive process (e.g.: stabbing, burning, twisting, tearing, and squeezing) and/or of a bodily or emotional reaction (e.g. terrifying, nauseating, and sickening) (Kumar and Elavarasi, 2016).

Balanites aegyptiaca (L.) Del, commonly called 'Desert date' in English, and locally called 'Aduwa' in Hausa, belongs to the family Balanitaceae. It is an evergreen xerophytic tree used in a variety of folk medicines in India and Africa where the plant is widely distributed. Various parts of the plants are used in Ayurvedic and other folk medicines for the treatment of different ailments such as syphilis, jaundice, liver and spleen problems, epilepsy, yellow fever and the plant also has insecticidal, anthelmintic, analgesic, molluscicidal and contraceptive activities. Significant anti-inflammatory activity was evaluated in methanol and ethanol extracts of the bark and leaf of $B$. aegyptiaca in two different animal models (Suky et al., 2011).

Analgesics, whether non-opioids or opioids have their toxicities and side effects, for example 
acetaminophen and the nonsteroidal antiinflammatory drugs (NSAIDs) are nephrotoxic. In addition, direct toxic effects of opioid analgesics that are extensions of their acute pharmacologic actions include respiratory depression, nausea, vomiting and constipation.

Furthermore, tolerance and dependence are problems associated with orthodox opioid analgesics. All these are a disadvantage (Tripathi, 2013). Therefore, there is a need for screening local plants for their promising abilities to cure or manage pain faster with minimal side effects. The aim of the study was to determine the antinociceptive and anti-inflammatory activities of the ethanol leaf extract of Balanites aegyptiaca Linn, which may justify the folklore use of the plant in the treatment of pain and painful stimulus.

\section{MATERIALS AND METHODS \\ Materials}

Some materials used included $2 \mathrm{~L}$ round bottom flask, $4 \mathrm{~L}$ Pyrex beaker, measuring cylinder, stainless steel tray and spatula, glass funnel, heating mantle, water bath, spatula, analytical balance, Whatman filter paper No. 4.

\section{Sample Collection, Identification and Extraction}

Fresh Balanites aegyptiaca Linn. leaves were collected from the Balanites population in the University of Maiduguri Campus, Maiduguri, Borno State, in January, 2018. The fresh plant material was taken to the Department of Biological Sciences, University of Maiduguri, where it was identified and authenticated by Prof. S.S. Sanusi and a voucher herbarium number of $542 \mathrm{C}$ was given. The leaves were washed with distilled water (to remove sand particles) and airdried under shade in the Pharmacology and Toxicology Laboratory, Faculty of Pharmacy, University of Maiduguri, for one week, after which the leaves were pulverized to powder using a wooden motar and pestle, weighted and stored in a polythene bag until when required.

\section{Extraction of Plant Material}

The method of extraction used was cold maceration where $625 \mathrm{~g}$ of the pulverized plant material was soaked in $95 \%$ ethanol then divided into two in a $5 \mathrm{~L}$ round bottom flask with shaking after every 24 hours for 72 hours. This was then filtered and subjected to drying using a rotary evaporator at $45^{\circ} \mathrm{C}$ which the dried extract was obtained and coded EEBA. After drying, extract was micronized using a porcelain mortar and a glass pestle, the colour of the aqueous extract was noted, then weighed and stored in a plastic container, labelled and kept in a cool and dry place for use throughout the research work. The percentage yield was calculated and recorded.

\section{Phytochemical Screening of EEBA}

Qualitative phytochemical test were carried using previously described methods (Sofowora, 2008; Evans, 2009).

\section{Pharmacological Studies \\ Experimental Animals}

Thirty-eight healthy adult albino rats of both sexes weighing 62-254 $\mathrm{g}$ were purchased from the Animal House, Department of Biochemistry, University of Maiduguri. They were kept in clean cages embedded with saw dust in the Department of Veterinary Physiology and Biochemistry Laboratory and were fed with Vital Feed Growers mash and drinking water ad libitum. The animals were allowed to acclimatize in the laboratory for a period of two weeks. Ethical methods approved by ICLAS and CIOMS (2012) were used in handling the animals.

\section{Acute Toxicity Studies ( $L D_{50}$ Determination)}

The acute toxicity of EEBA was determined as described by Lorke (1983). The experiment was divided into two phases both using the oral and intraperitoneal routes of administration as follows:

\section{Phase I}

Nine (9) healthy Wistar strain albino rats of both sexes (for each route) weighing 109-130 g were 


\section{Sodipo et al: Antinociceptive Effect of the Ethanol Leaf Extract of Balanites aegyptiaca Linn in...}

randomly selected and divided into three groups (labelled A, B and C) of three animals each. The groups were then treated respectively with the extract at incremental doses of $10 \mathrm{mg} / \mathrm{kg}, 100$ $\mathrm{mg} / \mathrm{kg}$, and $1000 \mathrm{mg} / \mathrm{kg}$ orally and intraperitoneally. The animals were then observed for 24 hours for signs of toxicity and mortality.

\section{Phase II}

Three (3) randomly selected healthy Wistar strain albino rats (for each route) weighing 175-254 g were grouped into three groups $A, B$ and $C$ of one animal each. The animals were then exposed to graded doses of EEBA orally and intraperitoneally $(1600 \mathrm{mg} / \mathrm{kg}, 2900 \mathrm{mg} / \mathrm{kg}$ and $5000 \mathrm{mg} / \mathrm{kg}$ ) respectively based on the results of phase I. The rats were allowed access to food and water ad libitum and were observed for 24 hours for signs of toxicity and mortality after which the LD50 was calculated using the formula below:

LD50 $=\sqrt{ } \mathrm{a} \times \mathrm{b}$

Where, $a=$ lowest dose that kills an animal, $1 / 1$

$b=$ highest dose that does not kill any animal, $0 / 1$ (Lorke, 1983).

\section{Hot Plate (Thermal Nociception) Test}

This was carried out according to the method described by Badilla et al. (2003). Twenty five rats of both sexes (weighing between 62-150 g) were randomly divided into five groups $(A, B, C$, $D$ and $E$ ) of five rats each. Those in group $A$ (negative control) received only distilled water (1 $\mathrm{ml} / \mathrm{kg}$ ), while those in groups $B, C$ and $D$ received 200,400 and $600 \mathrm{mg} / \mathrm{kg}$, respectively of EEBA whilst those in group $E$ (positive control) received pentazocine $(10 \mathrm{mg} / \mathrm{kg})$. All treatments were by i.p route. Thirty minutes later, they were placed on Eddy's hot plate, maintained at $55 \pm 0.5^{\circ} \mathrm{C}$. This was repeated every thirty minutes for 2 hours. The reaction time was taken as the time for the rats to jump out of the stainless steel plate on the hot plate. The $\%$ inhibition was then calculated.

\section{Tail Immersion Test}

Twenty five rats of both sexes (weighing 52.2-
$175.5 \mathrm{~g}$ ) were randomly divided into five groups ( $A, B, C, D$ and $E)$ of five rats each. Those in group $A$ (negative control) received only distilled water $(1 \mathrm{ml} / \mathrm{kg})$, while those in groups $B, C$ and $D$ received 200, 400 and $600 \mathrm{mg} / \mathrm{kg}$ respectively of EEBA whilst those in group $E$ (positive group) received pentazocine $(10 \mathrm{mg} / \mathrm{kg})$. All treatments were by i.p route. Thirty minutes later, their tails were immersed in the water bath, maintained at $55 \pm 0.5^{\circ} \mathrm{C}$. This was repeated every thirty minutes for 2 hours. The reaction time was taken as the time for the rats to remove their tail from the hot water in the water bath (Owoleye et al., 2004). The $\%$ inhibition in both cases was calculated using the following formula:

$\%$ inhibition=

Mean reaction time in test grp-Mean reaction time in neg control Mean reaction time in neg contro

\section{Statistical Analysis}

Data generated during the study were expressed as mean \pm standard deviation (S.D) and analysed by one-way analysis of variance (ANOVA) using Graphpad prism 3.1 version (2010). $p<0.05$ was considered significant.

\section{RESULTS}

The percentage yield obtained is shown in Table 1. The ethanol extract had a yield of $2.9 \% \mathrm{w} / \mathrm{w}$, the colour was green and had a fine texture. Phytochemical screening revealed that EEBA contains flavonoids, saponins, glycosides and carbohydrates but alkaloids, terpenoids, soluble starch and tannins were not detected or absent (Table 2).

Table 1: Extraction profile of ethanol leaf extract of Balanites aegyptiaca Linn

\section{Characteristics Ethanol Extract}

\begin{tabular}{ll}
\hline Yield $(\mathrm{g})$ & 625 \\
Colour & Green \\
Texture & Fine \\
$\begin{array}{l}\text { Percentage } \\
\text { yield }(\% \mathrm{w} / \mathrm{w})\end{array}$ & 2.9 \\
\hline
\end{tabular}


Nigerian Journal of Basic and Applied Science (December, 2019), 27(2): 39-46

Table 2: Preliminary phytochemical analysis of EEBA

\begin{tabular}{|c|c|c|c|c|}
\hline $\mathrm{S} / \mathrm{N}$ & Constituents & Test & Results & Observation \\
\hline 1. & Alkaloids & $\begin{array}{l}\text { (i) Dragendoff's test } \\
\text { (ii) Mayer's test }\end{array}$ & No precipitate formed & $\begin{array}{l}- \\
-\end{array}$ \\
\hline 2. & Anthraquinones & $\begin{array}{l}\text { (i) Free antraquinones test } \\
\text { Borntrager's test } \\
\text { (ii) Combined antraquinones test }\end{array}$ & $\begin{array}{l}\text { No precipitate formed } \\
\text { No violet colour formed }\end{array}$ & $\begin{array}{l}- \\
-\end{array}$ \\
\hline 3. & Carbohydrates & $\begin{array}{l}\text { (i)General (Molisch's) test } \\
\text { (ii) free reducing sugar (fehlin's) } \\
\text { test } \\
\text { (iii) combined reducing sugar } \\
\text { (iv) ketoses }\end{array}$ & $\begin{array}{l}\text { Purple colouration } \\
\text { Red precipitate formed } \\
\text { No colour change } \\
\text { No colour change }\end{array}$ & $\begin{array}{l}+ \\
+ \\
- \\
-\end{array}$ \\
\hline 4. & $\begin{array}{l}\text { Cardiac } \\
\text { glycosides }\end{array}$ & $\begin{array}{l}\text { (i)Libermann-Burchard's test } \\
\text { (ii)Salkowskis test }\end{array}$ & $\begin{array}{l}\text { Bluish-green colouration } \\
\text { Reddish-brown colouration }\end{array}$ & $\begin{array}{l}+ \\
+\end{array}$ \\
\hline 5. & Flavonoids & $\begin{array}{l}\text { (I)Ferric chloride test } \\
\text { (ii)Lead ethanoate test } \\
\text { (iii)Shinoda's test } \\
\text { (iv)Sodium chloride test }\end{array}$ & $\begin{array}{l}\text { No color change } \\
\text { No prcipitte formed } \\
\text { Light-pink colour }\end{array}$ & $\begin{array}{l}- \\
- \\
+ \\
+\end{array}$ \\
\hline $\begin{array}{l}6 . \\
7 .\end{array}$ & $\begin{array}{l}\text { Saponins } \\
\text { Tannins }\end{array}$ & $\begin{array}{l}\text { (i)Frothing test } \\
\text { (i)Ferric chloride test } \\
\text { (ii)Lead ethanoate test }\end{array}$ & $\begin{array}{l}\text { Foam formed } \\
\text { No color change } \\
\text { No precipitae }\end{array}$ & $\begin{array}{l}+ \\
- \\
-\end{array}$ \\
\hline 8. & Terpenoids & (i) Genral test & Violet precipitate formed & + \\
\hline
\end{tabular}

\section{Acute Toxicity}

$\mathrm{LD}_{50}$ studies of the ethanol leaf extract of Balanites aegyptiaca $\mathrm{L}$ gave an oral $\mathrm{LD}_{50}$ of $\geq$ $5000 \mathrm{mg} / \mathrm{kg}$ as shown in Table 3. $L D_{50}$ studies of the ethanol leaf extract of Balanites aegyptiaca $\mathrm{L}$. gave an intraperitoneal $L D_{50}$ of $2154 \mathrm{mg} / \mathrm{kg}$ as shown in Table 4.

Table 3: Oral acute toxicity $\left(L D_{50}\right)$ test of ethanol leaf extract of Balanites aegyptiaca $\mathrm{L}$.

\begin{tabular}{lllll}
\hline Phase & $\begin{array}{l}\text { No. of } \\
\text { Rats }\end{array}$ & $\begin{array}{l}\text { Dose } \\
(\mathbf{m g} / \mathbf{k g})\end{array}$ & $\begin{array}{l}\text { Clinical } \\
\text { signs }\end{array}$ & Mortality \\
\hline 1 & 3 & 10 & None & $0 / 3$ \\
1 & 3 & 100 & None & $0 / 3$ \\
1 & 3 & 1000 & None & $0 / 3$ \\
2 & 1 & 1600 & None & $0 / 1$ \\
2 & 1 & 2900 & None & $0 / 1$ \\
2 & 1 & 5000 & None & $0 / 1$ \\
\hline
\end{tabular}

Oral $L D_{50}$ is $>5000 \mathrm{mg} / \mathrm{kg}$
Table 4: Intraperitoneal acute toxicity $\left(\mathrm{LD}_{50}\right)$ test of the Ethanolic leaf extract of Balanites aegyptiaca L.

\begin{tabular}{lllll}
\hline Phase & $\begin{array}{l}\text { No. of } \\
\text { Rats }\end{array}$ & $\begin{array}{l}\text { Dose } \\
\text { (mg } / \mathbf{k g})\end{array}$ & $\begin{array}{l}\text { Clinical } \\
\text { signs }\end{array}$ & Mortality \\
\hline 1 & 3 & 10 & None & $0 / 3$ \\
1 & 3 & 100 & None & $0 / 3$ \\
1 & 3 & 1000 & None & $0 / 3$ \\
2 & 1 & 1600 & None & $0 / 1$ \\
2 & 1 & 2900 & None & $1 / 1$ \\
2 & 1 & 5000 & None & $1 / 1$ \\
\hline \multicolumn{5}{l}{ i.p LD } \\
\hline
\end{tabular}

\section{Antinociceptive and Anti-inflammatory Activity Hot Plate Test}

the antinociceptive effect of ethanol leaf extract Balanites aegyptiaca was dose dependent and statistically significant $(p<0.05)$ when doses of 200, 400 and 600 of were administered. This increased the pain threshold 30 minutes after intraperitoneal administration with a percentage 


\section{Sodipo et al: Antinociceptive Effect of the Ethanol Leaf Extract of Balanites aegyptiaca Linn in...}

inhibition of 50, 120 and $170 \%$ respectively, reaching the peak in 30 minutes. The inhibition produced by the extract was significantly $(p<0.05)$ lower when compared with that of the standard drug (pentazocine) which was $430 \%$. It was also observed that the percentage inhibition of both the extract and the standard drug decreased with time as depicted in Table 5.

\section{Tail Immersion Test}

The ethanol leaf extract of Balanites aegyptiaca at different post-treatment times induced a dosedependent increase in pain threshold (latency) for removal of tail. The maximum latency irrespective of post-treatment time for extract at doses of 200,400 and $600 \mathrm{mg} / \mathrm{kg}$ were $2.80 \pm$ $0.5,3.64 \pm 0.5$ and $4.40 \pm 0.5$ seconds, respectively when compared with a value of 5.76 \pm 0.5 for pentazocine. Pentazocine produced a greater inhibition compared with the extract $(600$ $\mathrm{mg} / \mathrm{kg}$ ) at all post-treatment times. Peak antinociceptive effect for the extract occurred at 90 minutes post-treatment (Table 6).

\section{DISCUSSION}

The results of phytochemical screening revealed that the ethanol leaf extract of $B$. aegyptiaca contained flavonoids, saponins, glycosides and carbohydrates. The phytochemicals have been reported to influence physiological activities of the body (Sofowora, 2008; Evans, 2009). The presence of these phytochemicals agrees with the work carried out on the stem barks of Balanites aegyptiaca Linn but alkaloids, anthraquinones and tannins were absent from their study (Ugwah et al., 2013).

The i.p $L D_{50}$ of $2154 \mathrm{mg} / \mathrm{kg}$ shows that the substance is non-toxic which agrees with the report of Kommu et al. (2013) of which the maximum tolerated dose was found to be 2000 $\mathrm{mg} / \mathrm{kg}$ b.w of the stem bark extract by oral administration using method of Organization of Economic Co-Operation and Development (OECD, 2011) as per 423 guidelines. According to Clarke and Clarke (1977), any substance whose i.p $L D_{50}$ in rats falls between 50 and 500 $\mathrm{mg} / \mathrm{kg}$ is toxic, above $500 \mathrm{mg} / \mathrm{kg}$ but less than $1000 \mathrm{mg} / \mathrm{kg}$ is moderately toxic and greater than $1000 \mathrm{mg} / \mathrm{kg}$ is non-toxic.

The effects of the extract in the hot plate and tail immersion methods demonstrated its analgesic action. In the hot plate and tail immersion experiments, pentazocine as an analgesic has a higher effect than that of the extract. The analgesic superiority is however, expected since pentazocine is a narcotic analgesic used to alleviate deep-seated pain (Turner, 1965; Besra et al., 1996).

Since there were significant activities recorded in both methods (hot plate and tail immersion), the extract could be said to act both peripherally and centrally in producing analgesia. Noxious stimuli cause the release of chemicals such as prostaglandins, decarboxylated amines (histamine and serotonin), thereby inducing pain locally (Nunez et al., 1997; Yongna et al., 2005). Peripherally acting analgesics such as nonsteroidal anti-inflammatory drugs (NSAIDs) act by inhibiting the release of prostaglandins (Wagner et al., 2004). The centrally acting analgesics such as pentazocine act through their receptors in the central nervous system (CNS) by increasing the pain threshold response to pain stimuli (Singh and Majumdar, 1995). Opioid analgesics inhibit both peripheral and central mechanisms of pain, while NSAIDs inhibit only peripheral pain (Elisabetsky et al., 1995).

This research work is in agreement with the report of Saboo et al. (2014) who evaluated the analgesic effect of the ethanol leaf extract of Balanites aegyptiaca in experimental rats using both the hot plate and tail immersion methods in which they reported significant analgesic activity in 30 minutes after oral doses of 200, 400 and $600 \mathrm{mg} / \mathrm{kg}$. Similarly, Gaur et al. (2008) reported a significant anti-inflammatory action on carrageenan-induced hind paw edema and analgesic activity of ethanol and petroleum ether extracts of aerial parts of $B$. aegyptiaca by using Eddy's hot plate method and tail-flick method in albinorats. 
Nigerian Journal of Basic and Applied Science (December, 2019), 27(2): $39-46$

Table 5: Effect of Ethanol leaf extract of Balanites aegyptiaca L. on hot plate in wister albino rats

\begin{tabular}{|c|c|c|c|c|c|c|c|c|c|}
\hline $\begin{array}{r}\text { Treatment } \\
\text { Group }\end{array}$ & $\begin{array}{c}\text { Dose } \\
(\mathrm{mg} / \mathrm{kg})\end{array}$ & $30 \mathrm{~min}$ & $\begin{array}{l}\% \text { increase } \\
\text { in pain } \\
\text { threshold }\end{array}$ & $\begin{array}{l}\text { Reaction } \\
60 \mathrm{~min}\end{array}$ & $\begin{array}{c}\text { Time } \\
\% \text { increase } \\
\text { in pain } \\
\text { threshold }\end{array}$ & $\begin{array}{c}\ln \\
90 \mathrm{~min}\end{array}$ & $\begin{array}{l}\text { Seconds } \\
\% \text { increase } \\
\text { in pain } \\
\text { threshold }\end{array}$ & $\begin{array}{c}\text { (Mean } \pm \text { SEM) } \\
120 \mathrm{~min}\end{array}$ & $\begin{array}{l}\% \text { increase } \\
\text { in pain } \\
\text { threshold }\end{array}$ \\
\hline $\mathrm{A}$ (Distilled water) & $1 \mathrm{ml}$ & $2.0 \pm 0.000^{a}$ & 0.00 & $2.0 \pm 0.00^{a}$ & 0.00 & $2.0 \pm 0.00^{a}$ & 0.00 & $1.8 \pm 0.20^{a}$ & 0.00 \\
\hline $\mathrm{B}(\mathrm{EEBA}-200)$ & 200 & $3.0 \pm 0.000^{b}$ & 50 & $3.4 \pm 0.25^{b}$ & 70 & $3.4 \pm 0.25^{b}$ & 70 & $3.0 \pm 0.55^{a}$ & 50 \\
\hline$C($ EEBA-400) & 400 & $4.4 \pm 0.25^{b}$ & 120 & $4.2 \pm 0.37^{b}$ & 110 & $3.4 \pm 0.25^{b}$ & 70 & $3.0 \pm 0.00^{a}$ & 50 \\
\hline D (EEBA-600) & 600 & $5.4 \pm 0.25^{b}$ & 170 & $4.4 \pm 0.25^{b}$ & 140 & $4.4 \pm 0.25^{b}$ & 120 & $3.4 \pm 0.245^{b}$ & 70 \\
\hline E (Pentazocine) & 10 & $10.6 \pm 0.25^{b}$ & 130 & $9.8 \pm 0.37^{b}$ & 390 & $9.6 \pm 0.25^{b}$ & 380 & $9.4 \pm 0.23^{b}$ & 370 \\
\hline
\end{tabular}

Table 6: Effect of ethanolic leaf extract of Balanites aegyptiaca L. on tail immersion on Wister Albino Rats

\begin{tabular}{|c|c|c|c|c|c|c|c|c|c|}
\hline $\begin{array}{l}\text { Treatment } \\
\text { Group }\end{array}$ & $\begin{array}{l}\text { Dose } \\
(\mathrm{mg} / \mathrm{k} \\
\mathrm{g})\end{array}$ & $30 \mathrm{~min}$ & $\begin{array}{l}\% \\
\text { increase } \\
\text { in pain } \\
\text { threshol } \\
\text { d }\end{array}$ & $\begin{array}{l}\text { Reaction } \\
60 \text { min }\end{array}$ & $\begin{array}{l}\text { Time } \\
\% \\
\text { increase } \\
\text { in pain } \\
\text { threshold }\end{array}$ & $\begin{array}{l}\ln \\
90 \min \end{array}$ & $\begin{array}{l}\text { Seconds } \\
\% \text { increase } \\
\text { in pain } \\
\text { threshold }\end{array}$ & $\begin{array}{l}\text { (Mean } \pm \text { SEM) } \\
120 \mathrm{~min}\end{array}$ & $\begin{array}{l}\% \\
\text { increase } \\
\text { in pain } \\
\text { threshol } \\
\text { d }\end{array}$ \\
\hline A(Distilled water) & $1 \mathrm{ml}$ & $2.16 \pm 0.16^{b}$ & 0.00 & $2.0 \pm 0.00^{b}$ & 0.00 & $2.08 \pm 0.04^{b}$ & 0.00 & $2.02 \pm 0.02^{b}$ & 0.00 \\
\hline $\mathrm{B}($ EEBA-200) & 200 & $2.78 \pm 0.08^{b}$ & 28.7 & $2.8 \pm 0.08^{b}$ & 40 & $2.64 \pm 0.14^{b}$ & 26.9 & $2.52 \pm 0.20^{\mathrm{a}}$ & 24.75 \\
\hline $\mathrm{C}(\mathrm{EEBA}-400)$ & 400 & $3.0 \pm 0.00^{\mathrm{b}}$ & 38.90 & $3.44 \pm 0.02^{b}$ & 72 & $3.64 \pm 0.35^{b}$ & 75 & $3.2 \pm 0.11 \mathrm{a}$ & 58.42 \\
\hline $\mathrm{D}($ EEBA-600) & 600 & $3.76 \pm 0.02^{b}$ & 74.10 & $3.92 \pm 0.05^{b}$ & 96 & $4.4 \pm 0.09 \mathrm{~b}$ & 111.5 & $3.48 \pm 0.16^{b}$ & 72.30 \\
\hline E (Pentazocine) & 10 & $4.88 \pm 0.24^{b}$ & 125.93 & $5.48 \pm 0.20^{\mathrm{b}}$ & 174 & $5.76 \pm 0.41^{b}$ & 176.92 & $4.72 \pm 0.05^{b}$ & 133.70 \\
\hline
\end{tabular}




\section{Sodipo et al: Antinociceptive Effect of the Ethanol Leaf Extract of Balanites aegyptiaca Linn in...}

The presence of flavonoids in EEBA may have contributed to observed analgesic effect. Flavonoids have been reported to possess analgesic activities (Ramaswamy et al., 1985). Flavonoids are known to inhibit the enzyme prostaglandin synthase, more specifically the endoperoxidase and reported to produce antiinflammatory effects. Since, prostaglandins are also involved in the pain perception; inhibition of their synthesis might be the possible reason for the analgesic activity of the ethanol extract.

\section{CONCLUSION}

The ethanol leaf extract of Balanites aegyptiaca Linn. is non-toxic, contained some phytochemicals which may possess analgesic and anti-inflammatory activities. The findings of this study shows some evidence for use of the plant in ethnomedical and folkloric practices in alleviating pain.

\section{REFERENCES}

Badilla, B., Arias, A., Mora, G. and Poveda, L. (2003). Anti-inflammatory and Antinociceptive Activities of Loasa speiosa in rats and mice. Fitoterapia, 74:645-705.

Besra, S. E., Sharma, R. M. and Gomis, A. (1996). Anti-inflammatory effect of petroleum extracts of the leaves of Lichi chinesis Gearten. Journal of Ethnopharmacology, 51:1-6.

Clarke, E. G. and Clarke, M. I. (1977). Veterinary Toxicology, 2nd Edition. New York: Bellaire Tindall. pp.10.

Elisabetsky, E., Amador, T. A., Albuquerque, R. R., Nunes, D. S. and Cavalho, A. C. (1995). Analgesic activity of Psychotria colorata. Journal of Ethnopharmacology, 48:77-83.

Evans, W. C. (2009). Trease and Evans Textbook of Pharmacognosy 16th ed. WB Saume Company Ltd. 24-25 Oval, London. NW7DX, UK and printed by Harcourt Brace and Company Asiapte Led 583 Orchard Road No. 09-01 form Singapore, Pp: 13-53, 117-139,227, 334,
471-551.

Gaur, K., Nema, R. K. Kori, M. L. Sharma, C. S. and Singh, V. (2008). Anti-inflammatory and analgesic activity of Balanites aegyptiaca in experimental animal models, International Journal of Green Chemistry, 2: 214-217.

Kommu, S., Gowrishankar, N.L., Kamala, D., Saritha, B., Srinivasulu, V., Naresh, B., Sandeep, K., Nagesp, P. (2013) Evaluation of Wound Healing Activity of Methanolic Extract of Balanites aegyptiaca L. Leaves. International Journal of Pharmacy and Pharmaceutical Sciences, 5: 52-53.

Kumar, H. J. and Elavarasi, I. (2016). The use of NSAIDs: a Science Advisory from the American Heart Association. American Heart Association Journal, 17(1): 80-86.

Lorke, D. (1983). A new approach to practical acute toxicity testing. Journal of Toxicology, 54:275-27.

Nunez, G. M., Emim, J. A., Soucar, C. and Lapa, A. J. (1997). Analgesic and Antiinflammatory activities of the aqueous extract of Plantago major L. International Journal of Pharmacognosy, 35(2):99104.

OECD (2001). Organization of Economic CoOperation and Development 425 guidelines. OCED Guidelines for testing animals:1-26.

Owoleye, B. V., Olaleye, S. B., Oke, J. M. and Elegbe, R. A. (2004). Anti - Inflammatory and Analgesic Activities of Nothospondias staudtii. Nigerian Journal of Physiological Science, 19(1-2): 102105.

Ramaswamy, S, Pillai, N. P., Gopalkrishnan, V., Parmar, N.S., Ghosh, M. N. (1985). Analgesic effect of $\mathrm{O}$-( $\beta$-hydroxyethyl) rutoside in mice. Indian Journal of Experimental Biology, 23:219.

Saboo, S. S., Chavan, R. W., Tapadiya, G. C. and Khadabadi, S. S. (2014). An important Ethnomedicinal Plant Balanites egyptiaca Del. International Journal of 
Phytopharmacy, 4(3): 75-78.

Singh, S. and Majumdar, D. K. (1995). Analgesic activity of Ocimum sanctum and its possible mechanism of action. International Journal of Pharmacognosy, 33:188-192.

Sofowora, E.A. (2008). Medicinal plants and Traditional Medicine in Africa. Spectrum Books Ltd.3rd ed. Ibadan, Nigeria, Pp.289.

Suky, G. M., Parthipan, B., Kingston, C. and Mohan, V. R. (2011). Anti-inflammatory Activity of Aerial Part of Balanites aegyptiaca L. (Del) against Carrageenan-induced Paw Edema. International Journal of PharmTech Research, 3(2): 639-643.

Tripathi, K. D. (2013). Essentials of Medical Pharmacology. $7^{\text {th }}$ edition. Jaypee Brothers Medical Publishers (P) Ltd, New Delhi, India. Pp. 469-486.

Turner, R. A. (1965). Screening Methods in Pharmacology, New York Academy Press. Pp. 105-108.

Ugwah, M. O., Etuk, E. U., Bello, S. O., Aliero, A. A. and Chinenye, U. O. (2013). Comparative studies of the antiulcerogenic activities of three Nigerian medicinal plants: A preliminary evaluation. Journal of Medicinal Plants Research, 7(9):490-495.
Wagner, W., Khanna, P. and Furst, D. E. (2004). Non-steroidal Anti-inflammatory Drugs, disease modifying antirheumatoid drugs, non opiod analgesics and drugs used in gout. In. B. G. Katzung, Basic and Clinical Pharmacology, $9^{\text {th }}$ Edition, $p$. 577.

Yongna, Z., Wapana, R., Pisit, B., Zhongkun, L. and Rongpin, Z. (2005). Analgesic and antipyretic activities of the aqueous extract of Urtica marcrorrhiza in experimental animals. Fitoterapia. 75:9195. 